\title{
Perilaku Hidup Bersih dan Sehat (PHBS) serta Diare Akut di SMP Plus Pesantren Baiturrahman Bandung
}

\author{
Novy Latifah Nurul F, ${ }^{1}$ Fajar Awalia Yulianto,2 Yoyoh Yusroh, ${ }^{3}$ \\ Siska Nia Irasanti, ${ }^{4}$ Dony Septriana Rosady 5 \\ ${ }^{1}$ Prodi Studi Pendidikan Dokter, Fakultas Kedokteran, Universitas Islam Bandung, \\ ${ }^{2}$ Departemen Ilmu Kesehatan Masyarakat, Universitas Islam Bandung \\ ${ }^{3}$ Departemen Ilmu Kesehatan Anak, RSUD Al-Ihsan Provinsi Jawa Barat, \\ ${ }^{4}$ Departemen Ilmu Kesehatan Masyarakat, Universitas Islam Bandung, \\ ${ }_{5}^{5}$ Departemen Ilmu Kesehatan Masyarakat, Universitas Islam Bandung
}

\begin{abstract}
Abstrak
Angka morbiditas dan mortalitas akibat penyakit diare di dunia masih sangat tinggi terutama di negara berkembang. Diare merupakan penyebab kematian ke-4 pada golongan semua usia di Indonesia serta angka morbiditasnya menempati urutan ke-5 di Kota Bandung. Faktor risiko diare berkaitan dengan program Perilaku Hidup Bersih dan Sehat (PHBS). Penelitian ini bertujuan mengetahui apakah terdapat hubungan antara PHBS dan kejadian diare akut pada siswa kelas VIII SMP Plus Pesantren Baiturrahman Bandung. Penelitian ini menggunakan metode observasional analitik dengan pendekatan cross sectional dilaksanakan periode Mei 2018. Subjek terdiri atas 140 responden, secara consecutive sampling. Pengambilan data menggunakan kuesioner yang berisi pertanyaan mengenai PHBS tatanan intitusi pendidikan serta kejadian diare akut. Uji statistik menggunakan chi square. Hasil penelitian didapatkan lebih banyak responden yang tidak melakukan PHBS (55\%) dibanding dengan responden yang melakukan PHBS (45\%). Sebagian besar tidak mengalami diare akut (75\%) dan hanya sebagian kecil mengalami diare akut (25\%) $(\mathrm{p}=0$,001). Simpulan, terdapat hubungan antara PHBS dan kejadian diare akut pada siswa kelas VIII SMP Plus Pesantren Baiturrahman Bandung. Penelitian ini menunjukkan praktik PHBS pada lingkup siswa SMP penting.
\end{abstract}

Kata kunci: Diare akut, kesehatan masyarakat, PHBS

\section{Clean Living and Healthy Behaviours and Acute Diarrhea in Junior High School of Baiturrahman Boarding School Bandung}

\begin{abstract}
The number of morbidity and mortality due to diarrhea disease in the world is still high, especially in the developing countries. Diarrhea is the fourth cause of death in all age groups in Indonesian, with the morbidity number ranks fifth in Bandung city. Some of risk factors of diarrhea are related with the Clean Living and Healthy Behaviours (Perilaku Hidup Bersih dan Sehat=PHBS). This research was aimed to analyze the relationship between PHBS and the occurance of acute diarrhea in 8th grade Junior High School students of Baiturrahman Boarding School Bandung. This research used observational analytic method with cross sectional approach during May 2018. The subjects obtained 140 respondents in consecutive sampling. Data retrieval used questionnaire which contains the questions about PHBS and the occurance of acute diarrhea. Statistical test used chi square with SPSS. The result of the research shows that more respondents did not do PHBS (55\%) than respondents who do PHBS (45\%). The number of occurance of acute diarrhea mostly did not occur acute diarrhea (75\%) and some had acute diarrhea (25\%). Chi square test results obtained $\mathrm{p}$ value $=0.001$. Therefore it can be concluded that there is a relationship between PHBS and the occurance of acute diarrhea in $8^{\text {th }}$ grade Junior High School students of Baiturrahman Boarding School Bandung. It is very impotance to do PHBS on the scope of junior high school students.
\end{abstract}

Keywords: Acute diarrhea, PHBS, public health

Korespondensi: Novy Latifah Nurul F. Program Studi Pendidikan Dokter. Alamat: Jl. Tamansari No.20, Bandung 40116, Provinsi Jawa Barat Telepon: 0224203368 Faksimile: 0224203368 Email: novylatifah@gmail.com. 


\section{Pendahuluan}

Indonesia tengah menghadapi tantangan besar, yakni masalah kesehatan triple burden sehingga Kementerian Kesehatan (Kemenkes) RI secara khusus mengingatkan masyarakat untuk menjaga kesehatan melalui Gerakan Masyarakat Hidup Sehat (GERMAS) guna mewujudkan Indonesia sehat pada tahun 2020. ${ }^{1}$ Untuk terciptanya program tersebut dibentuk sekumpulan perilaku yang dipraktikkan atas dasar kesadaran sebagai hasil pembelajaran yang menjadikan seseorang mampu menolong dirinya sendiri (mandiri) di bidang kesehatan dan berperan aktif dalam mewujudkan kesehatan masyarakat yang disebut dengan PHBS.

Perilaku Hidup Bersih dan Sehat (PHBS) terbagi dalam lima tatanan, salah satunya tatanan institusi pendidikan atau sekolah yang memiliki beberapa contoh indikator, yaitu mencuci tangan dengan air yang mengalir dan menggunakan sabun, mengonsumsi makanan dan minuman sehat, menggunakan jamban yang bersih dan sehat, serta membuang sampah pada tempatnya. ${ }^{2}$

Penyakit diare sampai saat ini masih merupakan salah satu penyebab utama morbiditas dan mortalitas. Secara umum diare membunuh sekitar 2,2 juta orang setiap tahun dan kebanyakan adalah anak di negara berkembang. ${ }^{3}$ Diare merupakan penyakit endemis di Indonesia dan merupakan penyakit potensial kejadian luar biasa (KLB) yang sering disertai dengan kematian. Menurut hasil Riskesdas 2013, diare merupakan penyebab kematian ke-4 pada golongan semua usia. ${ }^{4}$

Profil kesehatan Provinsi Jawa Barat tahun 2014 dinyatakan jumlah perkiraan kasus diare yang terjadi di Provinsi Jawa Barat sebanyak 990.832. Kota Bandung sendiri menempati urutan ke- 5 pada golongan semua usia. ${ }^{5}$ Tahun 2014 terdapat 55.115 perkiraan kasus diare yang tersebar di 30 kecamatan. Di kecamatan Ujungberung, di UPT Ujungberung Indah memiliki angka yang cukup tinggi dalam kasus diare, yakni 1.686 orang (laki-laki 856 dan perempuan 831). ${ }^{6}$

Murid Sekolah Menengah Pertama (SMP) kelas VIII yang pada umumnya berusia 14 tahun secara perkembangan psikososial, fokus perhatian utamanya adalah pada masa sekarang dan teman sebaya. Pada tahapan ini mereka akan menunjukkan perannya dengan bergaya sebagai seseorang yang sangat dekat dengan kelompoknya, serta bergaul dengan mengadopsi nilai kelompok dan lingkungannya. Hal ini dapat memengaruhi perilaku anak baik dalam pergaulan ataupun dalam hal waktu makan, makanan yang dikonsumsi, maupun cara mereka makan. ${ }^{7,8}$

Pesantren merupakan salah satu tempat umum seperti rumah sakit, sekolah, dan kantin. Di dalamnya terdapat asrama, masjid, dan sekolah para santri yang tinggal dan melakukan aktivitas sehari-hari di lingkungan pesantren. Kegiatan yang dilakukan setiap harinya di pesantren dapat berpotensi kemungkinan terjadi penularan penyakit, pencemaran lingkungan, maupun gangguan kesehatan lainnya. Diare dapat

Tabel 1 Kuesioner Penelitian

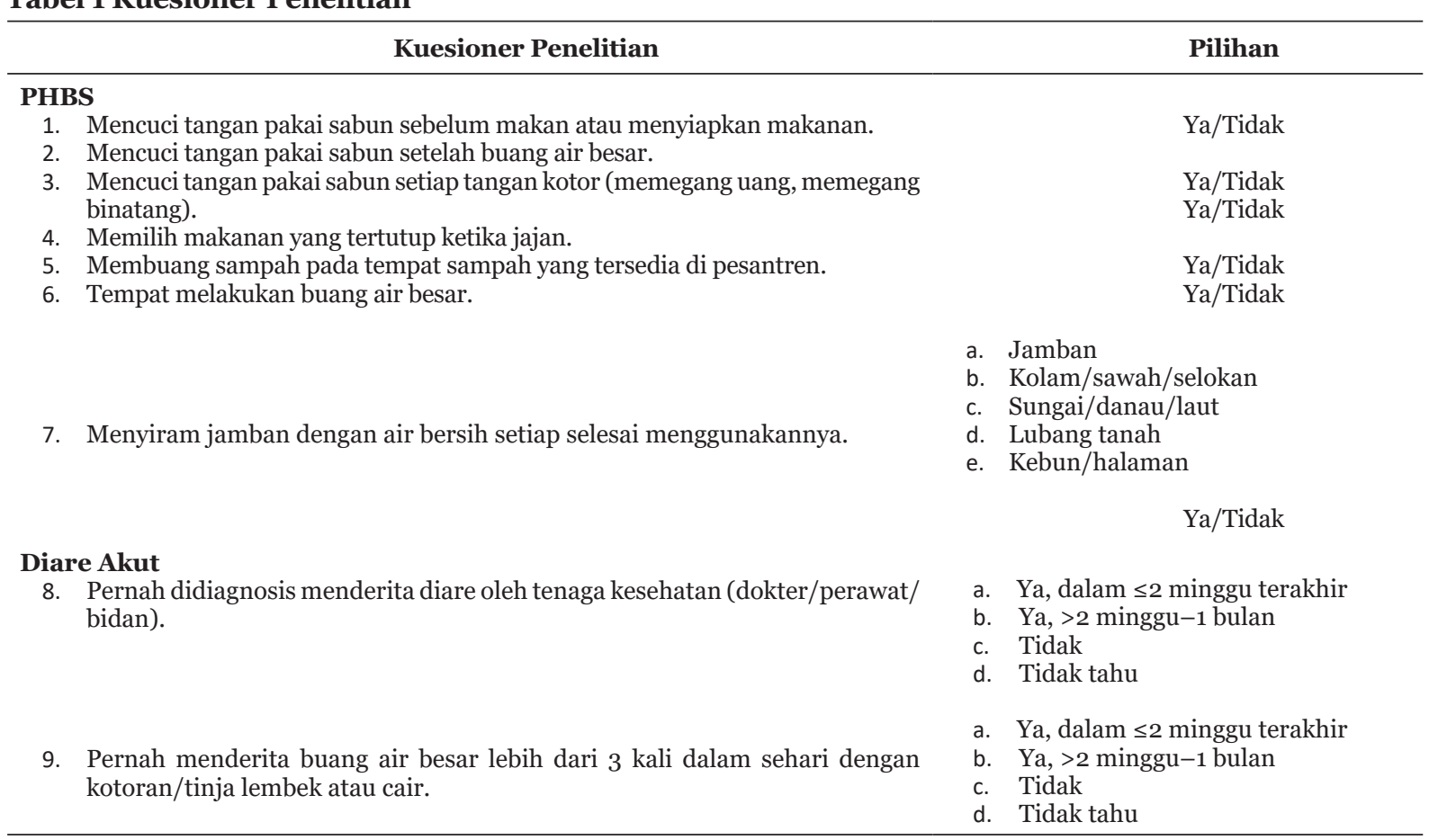

Ket: Ber-PHBS bila menjawab "ya” pada semua kriteria pertanyaan

Sumber: Riskesdas dan Universitas Negeri Yogyakarta 9,11 
terjadi apabila faktor lingkungan yang tidak sehat karena pencemaran kuman penyebab diare serta berakumulasi dengan perilaku manusia yang tidak sehat atau PHBS yang buruk.

Berdasar atas latar belakang yang telah diuraikan maka tujuan penelitian ini adalah mengetahui gambaran perilaku hidup bersih dan sehat serta jumlah kejadian diare akut pada siswa Kelas VIII SMP Plus Pesantren Baiturrahman Bandung; dan menganalisis apakah ada hubungan perilaku hidup bersih dan sehat dengan kejadian diare akut.

\section{Metode}

Metode penelitian yang digunakan dalam penelitian ini adalah observasional analitik dengan pendekatan crosssectional. Populasi ini adalah siswa kelas VIII SMP Plus Pesantren Baiturrahman Bandung. Pengambilan sampel dari subjek kasus dilakukan dengan cara consecutive sampling. Dalam penelitian ini ukuran sampel ditentukan menggunakan rumus besar sampel uji hipotesis beda 2 proporsi didapatkan total sampel minimal 44 orang untuk setiap kelompok. Sampel dipilih dengan memenuhi kriteria inklusi, yaitu siswa kelas VII dan IX SMP Plus Pesantren Baiturrahman Bandung yang hadir saat waktu penelitian berlangsung dan bersedia mengisi penelitian dengan menandatangani lembar persetujuan (informed consent). Kriteria eksklusi adalah memiliki penyakit dan kelainan pada sistem saluran cerna seperti typhoid dan crohn's disease.

Instrumen yang digunakan adalah kuesioner yang telah divalidasi dan dimodifikasi dari indikator PHBS di tatanan institusi pendidikan. Kuesioner perilaku PHBS anak sekolah terdiri atas 8 pertanyaan. ${ }^{9}$ Siswa yang dikatakan ber-PHBS adalah siswa yang memiliki skor sama dengan $8 .^{10}$ Kuesioner kejadian diare akut anak sekolah dinilai dengan kuesioner dari Riset Kesehatan Dasar Kementrian Kesehatan Republik Indonesia tahun 2013. ${ }^{11}$

Peneliti melakukan pengambilan data pada tanggal 7-10 Mei 2018 dan bertempat di SMP Plus Pesantren Baiturrahman Bandung. Uji statistik menggunakan uji chi square dengan $\alpha=0,05$. Penelitian ini sudah mendapat persetujuan etik oleh Komite Etik Penelitian Kesehatan Fakultas Kedokteran Universitas Islam Bandung dengan Nomor: 351/Komite Etik.FK/ III/2018.

\section{Hasil}

Tabel 2 Karakteristik Responden berdasar atas Jenis Kelamin dan PHBS

\begin{tabular}{lcc}
\hline $\begin{array}{l}\text { Jenis Kelamin } \\
\text { dan PHBS }\end{array}$ & $\begin{array}{c}\text { Jumlah } \\
\text { (n) }\end{array}$ & $\begin{array}{c}\text { Persentase } \\
\text { (\%) }\end{array}$ \\
\hline Jenis kelamin & & \\
$\quad$ Perempuan & 72 & 51 \\
$\quad$ Laki-laki & 68 & 49 \\
PHBS & & \\
Tidak & 77 & 55 \\
Ya & 63 & 45 \\
\hline
\end{tabular}

Responden lebih banyak perempuan (51\%) daripada laki-laki (49\%). Responden tidak PHBS sebanyak 55\%. (Tabel 2)

Tabel 3 Jumlah Kejadian Diare Akut

\begin{tabular}{lcc}
\hline $\begin{array}{c}\text { Kejadian Diare } \\
\text { Akut }\end{array}$ & n=140 & $\begin{array}{c}\text { Persentase } \\
\text { (\%) }\end{array}$ \\
\hline Ya & 35 & 25 \\
Tidak & 105 & 75 \\
\hline
\end{tabular}

Sebagian besar siswa kelas VIII SMP Plus Pesantren Baiturrahman Bandung tidak mengalami kejadian diare akut (75\%).

Tabel 4 Hubungan PHBS dengan Kejadian Diare Akut

\begin{tabular}{|c|c|c|c|c|c|c|}
\hline \multirow{3}{*}{ PHBS } & \multicolumn{4}{|c|}{ Kejadian Diare Akut } & \multirow{3}{*}{$\begin{array}{c}\text { Nilai } \\
\mathbf{p}\end{array}$} & \multirow{3}{*}{$\mathbf{P R}$} \\
\hline & \multicolumn{2}{|c|}{ Terjadi } & \multicolumn{2}{|c|}{ Tidak Terjadi } & & \\
\hline & $\mathbf{n}=\mathbf{3 5}$ & $\%$ & $\mathbf{n}=\mathbf{1 0 5}$ & $\%$ & & \\
\hline $\mathrm{Ya}$ & 28 & 36 & 49 & 64 & 0,001 & 1,8 \\
\hline Tidak & 7 & 11 & 56 & 89 & & \\
\hline
\end{tabular}

Siswa kelas VIII SMP Plus Pesantren Baiturrahman yang melakukan PHBS tidak terjadi diare lebih tinggi, yaitu $89 \%$ dibanding dengan siswa yang tidak ber-PHBS sebesar $64 \%(p=0,001)$ berarti terdapat hubungan antara PHBS dan kejadian diare akut. $\mathrm{PR}=1,8$ artinya tidak ber-PHBS merupakan salah satu faktor risiko diare akut.

Hasil yang didapatkan pada penelitian ini selaras dengan hasil penelitian Saputro dkk. ${ }^{16}$ tentang anak sekolah dasar bahwa beberapa indikator dalam PHBS seperti menggunakan jamban sehat, kebiasaan mencuci tangan menggunakan sabun, mengonsumsi jajanan sehat, dan buang sampah pada tempatnya memengaruhi kejadian diare pada anak sekolah $(\mathrm{p}=0,001)$. Kejadian diare lebih besar pada anak yang tidak berperilaku hidup bersih dan sehat, serta angka kejadian diare lebih kecil pada anak yang berperilaku hidup bersih dan sehat.

Terdapat hubungan antara PHBS dan kejadian diare akut sesuai dengan faktor risiko terjadi diare, yaitu faktor perilaku dan faktor lingkungan yang buruk. Diare juga dapat menyebar dari orang ke orang yang diperparah oleh kebersihan diri yang buruk. Makanan merupakan penyebab utama diare jika disiapkan atau disimpan dalam kondisi tidak higienis. ${ }^{3}$

Empat indikator utama PHBS tatanan sekolah yang buruk (mencuci tangan menggunakan sabun, menggunakan jamban sehat, mengonsumsi makanan dan minuman sehat, serta membuang sampah pada tempatnya) sangat berhubungan dengan kejadian diare akut pada siswa karena dapat membuka rantai infeksi suatu patogen atau mikroorganisme sehingga dapat terjadi infeksi dan menyebabkan diare akut. 


\section{Pembahasan}

Tucunan $^{12}$ melakukan penelitian hubungan faktor predisposing, enabling dan reinforcing dengan perilaku hidup bersih dan sehat tatanan rumah tangga pada awal tahun 2018 di Provinsi Sulawesi Utara, ternyata praktik melakukan PHBS sehari-hari dipengaruhi oleh beberapa faktor, dan yang paling memengaruhi adalah pengetahuan serta sikap.

Seseorang yang mempunyai pengetahuan baik akan melakukan perilaku yang positif karena apa yang dia ketahui akan digunakan dalam melakukan berbagai tindakan, dalam hal ini tindakan PHBS. Begitu pula dengan sikap yang secara otodidak berhubungan signifikan dengan PHBS. Seseorang yang memiliki sikap baik, cenderung ingin melakukan sesuatu yang positif pula, ini didorong oleh keinginan untuk melakukan sesuatu yang benar berdasar atas sikap yang mereka miliki. Orang yang bersikap baik dipengaruhi oleh pengetahuan yang ia miliki sehingga dari sikap tersebut ia akan berupaya mengaktualisasikan dengan tindakan nyata sehingga tergambar apa yang ia yakini benar dapat dilakukannya. ${ }^{12}$

Distribusi kejadian diare berbeda dengan penelitian yang dilakukan oleh $\mathrm{Hadi}^{13}$ tentang santri Pondok Tremas Kabupaten Pacitan sebagian besar mengalami kejadian diare $(54,9 \%)$.

Perbedaan ini disebabkan oleh kejadian diare dalam periode tiga bulan yang memungkinkan peluang kejadian diare lebih sering, sedangkan kejadian diare peneliti adalah kejadian diare dalam periode yang cukup singkat, yaitu 2 minggu. ${ }^{13}$

Hasil penelitian ini berbeda dengan hasil penelitian yang dilakukan oleh Waromi dkk. ${ }^{14}$ di Desa Ranowangko Kecamatan Tombariri Kabupaten Minahasa tidak terdapat hubungan antara PHBS dan kejadian diare $(\mathrm{p}=0,71)$. Pada penelitian tersebut jumlah anak yang ber-PHBS, namun mengalami diare lebih besar dibanding dengan anak yang ber-PHBS, namun tidak mengalami diare ( $30 \%$ vs $24,4 \%$ ). Hal ini dapat terjadi disebabkan oleh faktor-faktor lain yang menyebabkan kejadian diare seperti lingkungan, ketersediaan air bersih, dan status gizi. ${ }^{15}$

\section{Simpulan}

Hasil penelitian didapatkan bahwa sebagian besar siswa kelas VIII SMP Plus Pesantren Baiturrahman Bandung tidak menerapkan PHBS, tidak mengalami kejadian diare akut, dan terdapat hubungan Perilaku Hidup Bersih dan Sehat (PHBS) dengan kejadian diare akut.

\section{Ucapan Terima Kasih}

Pada kesempatan ini penulis menyampaikan terima kasih kepada pimpinan serta siswa SMP Plus Pesantren Baiturrahman Bandung yang sudah memberikan izin penelitian ini.

\section{Daftar Pustaka}

1. Kementerian Kesehatan Republik Indonesia. Gerakan masyarakat hidup sehat (GERMAS). 2016 [diunduh 2018 Feb 6]. Tersedia dari: http:// www.depkes.go.id/article/view/16111600003/ pemerintah-canangkan-gerakan-masyarakathidup-sehat-germas-.html.

2. Departemen Kesehatan RI. Pedoman pembinaan prilaku hidup bersih dan sehat. 2011. [diunduh 25 Januari 2018]: Tersedia dari: www.depkes.go.id.

3. WHO|Diarrhoea. WHO. 2016 [diunduh 25 Januari 2018]: Tersedia dari: http://www.who. int/topics/diarrhoea/en/

4. Badan Penelitian dan Pengembangan Kesehatan. Riset kesehatan dasar (Riskesdas). 2013. Laporan Nasional 2013. Jakarta. Kementerian Kesehatan RI; 2013

5. Kementerian Kesehatan RI. Profil kesehatan Indonesia 2014 [diunduh 25 Januari 2018]: Jakarta: Kementerian Kesehatan Republik Indonesia; 2015. Tersedia dari: http://www. depkes.go.id/resources/download/pusdatin/ profil-kesehatan-indonesia/profil-kesehatanindonesia-2014.pdf

6. Kasus diare menurut jenis kelamin, kecamatan, dan puskesmas. Tabel profil kesehatan Kota Bandung tahun 2014. Bandung: Dinkes Prov Jabar; 2014.

7. Marcdante KJ, Kliegman RM, Jenson HB, Behrman RE. Penilaian sistem pencernaan. Nelson ilmu kesehatan anak esensial. Edisi ke6. Jakarta: Ikatan Dokter Anak Indonesia; 2014. hlm. 459, 481-4.

8. James SB, Alcott SV. Teori personaliti dan psikopatologi. Dalam: ...............penyunting Kaplan \& Sadock buku ajar psikiatri klinis. Edisi ke-10. Jakarta: EGC; 2007. hlm. 284.

9. Universitas Negeri Yogyakarta. Kuesioner perilaku hidup bersih dan sehat pada siswa di sekolah. 2015.

10. Dinas Kesehatan Provinsi Jawa Barat. Petunjuk teknis PHBS tatanan rumah tangga. Seri petunjuk Teknis PHBS. Bandung: Dinkes Prov Jabar; 2016.

11. Kementrian Kesehatan RI. Kuesioner riset kesehatan dasar. Jakarta: Kemenkes RI; 2013.

12. Tucunan A. Hubungan antara faktor predisposing, enabling dan reinforcing dengan perilaku hidup bersih dan sehat tatanan rumah tangga. KESMAS. 2018;7(1):62-8.

13. Hadi MI. Hubungan perilaku hidup bersih dan sehat (PHBS) terhadap angka kejadian diare akut pada santri pondok tremas kabupaten pacitan. [diunduh 18 Agustus 2018]. Tersedia dari: http:// v2.eprints.ums.ac.id/archive/etd/558412017.

14. Waromi K, Akili RH, Kawatu PAT. Hubungan antara PHBS dengan kejadian diare di Desa Ranowangko Minahasa tahun 2015. J Ilmiah Farmasi. 2016;5(4):284-90.

15. Departemen Kesehatan RI. Buku saku petugas kesehatan lintas diare. Jakarta: Direktorat Jendral Pengendali Penyakit dan Penyehatan Lingkung; Departemen Kesehat RI, 2011.

16. Saputro W, Budiarti LY, Herawati. Perilaku hidup bersih dan sehat (PHBS) dengan kejadian diare pada anak sekolah dasar (SD). JDK. 2013;1(1):40-7. 